\title{
Ayn Rand's Utopian Visions in Theory and Realization
}

\author{
By Ben Sapet
}

$\cos$

\section{ABSTRACT}

Ayn Rand sought to reframe the world around a distinctly utopian sense of domineering individualism. Her philosophy vilified altruism and extolled selfishness in the name of her human ideal. With its unwavering faith in the free market and adoration of industrial magnates, Rand's often problematic philosophy has gone on to shape American economic and political models. This essay explores how Rand's philosophy manifested in her fiction and, in turn, in American culture. 
To seriously study Ayn Rand is a political, often taboo, act. Philosophers rarely take time to refute her ideas and critics rarely analyze her work. Perhaps rightly, there is a certain stigma attached to Rand scholarship. That stigma comes from the idea that, regardless of the scholar's stance, bringing Rand into critical conversation condones her philosophy by legitimizing it. This reservation comes, in part, from a fear of being associated with Rand's fervid defenders and from the iconoclastic power of her ideas.

Ayn Rand wrote in the tradition of philosophical fiction, also known as the novel of ideas. In philosophical fiction, authors use storytelling rather than discursive philosophy to convey an ideology or a way of seeing the world. Rand's novels The Fountainhead and Atlas Shrugged follow this convention as they seek to situate and demonstrate a guiding ethic for the world. Rand's ethic came to be known as Objectivism. At its core, Objectivism sought to re-center philosophy and policy around the individual-the antithesis to the collectivist movements she saw forming around the world.

These ideas took hold in the contemporary American society as they interwove with the national myths of meritocracy, earning one's place, and rugged individualism. Not only do Rand and her philosophy maintain a devout following, but her books continue to sell extraordinarily well and spread to new audiences. As Rand's ideas merged with conservatism in the Reagan era and more recently with the Tea Party movement, her philosophy has come "to live just as much in the real world as in her fictional worlds." Analyzing Rand's ideas and methods through the lens of utopian thinking offers insights as to how her utopian view of America inspired conservative-libertarian economic and political movements with far-reaching influence. Studying the appeal of these guiding utopian ethics and ideals offers an opportunity to study how they have been realized and systematized.

Writing in such a contentious area, I (like many others who write about Rand) feel it's best that I acknowledge my personal stance. I find her beliefs-in unfettered, laissez-faire capitalism, and placing the self above others-problematic and often destructive. At the same time, however, these beliefs have a distinct power-especially given her ability to situate them in vivid fictional, utopian/dystopian worlds and characters. As her ideas have leaked out from static literary worlds and nonfiction essays into real-world policy and attitudes, scholars have a profound opportunity to better understand the now foundational political and economic beliefs of the modern world by studying 
Rand and her impact.

\section{WHAT IS OBJECTIVISM?}

Rand grounded her philosophy in the idea that an objective reality carries on apart from human consciousness-hence the name, "Objectivism." Given this reality, Rand places the onus of pursuing knowledge and satisfaction on humans. She lionizes this pursuit alongside humans with the hunger to take what they want from that reality. In that sense, Rand divides people into the earned and unearned, the creators and consumers. As they appear in her literature, the "earned" are often the titans of industry who take what they want and innovate to get there. These movers and shakers are what we might call "the one-percent," the ones whose relentless self-interest leads them to innovate and shape the landscape of reality. Rand's first major novel, The Fountainhead, depicts the struggle of an ambitious architect whose innovative designs draw the ire of critics, writers, publishers, and other architects who disparage the change. The hero-protagonist, Howard Roark, must resist the overwhelming pressures of conformity and push back against this "unearned" established mindset to make his mark on reality. For Rand, the "unearned" are those who leech off others' innovation and progress. Relying on others to prop oneself up is a cardinal sin in Objectivism. Rand identifies and detests the sort of passiveness of every day monotonous life. The heroes are those who bend reality around themselves, while the villains are the majority who coast through that reality untroubled by the valiant efforts of those who create.

Alongside self-interest and taking lies the Randian value of creation. With the Objectivist view of an immutable reality lies the foundation for those "earned" and "unearned" in terms of how they relate to that reality, whether they are a participant in it who makes their mark or a person buffeted by that reality. She sees the ultimate human heroism as creating and negotiating the trappings of that

reality. As an author, Rand follows this spirit of creativity and negotiation in her work. Existing social structures, such as socialism and religion, that oppose her view of human nature become targets in fiction. She seeks to advance her own philosophy while breaking down collectivism and the "flock" mentality. To do this, she opts to create utopian worlds conceived of as an idealized conflict between her heroic innovators and the sheep who follow in tow. 
The worlds in Rand's works of fiction serve to establish her philosophy in the context of imagined, exaggerated worlds where character tension and ideological clashes are elevated to a dramatic, worldshaking level. Rand creates some of this tension by placing utopia inside and alongside dystopia, such as capitalist havens inside increasingly collectivist societies. The utopian communities are treated as

the last bastion of human heroism in the face of systems and trends that lead people to a passive life of impeding progress. This stands in stark contrast to many dystopias in which progress and the people who strive for it are the ones who endanger society. Like many utopian thinkers, Rand's utopian leanings center on idolizing an extreme reversal of the status quo. For Rand, that extreme reversal involves shedding the government incentives and nationwide social programs that characterized the American government in the 1940s and 50s. She saw taxation to benefit society as theft that facilitated leeching from the most productive members of society. With the looming growth of socialism and communism, Rand's utopias sought to reinforce the promises of capitalism and the American ideals that brought her to America from her native Russia.

\section{UTOPIA IN RAND'S LITERATURE}

Rand's first mainstream novel, The Fountainhead, reflects the early stages of Objectivism. It focuses on her ethic of heroic creativity in the face of an objective reality populated by collectivists, who push down individualism in favor of unchallenging mediocrity. This focus on individualism and ferocious creativity came to Rand after spending fifteen years in the United States, a country with values and systems that aligned with her ambition and iconoclastic thinking. Given her exposure to freedom and the opportunity to pursue her desire, she explores the motivation to do so and separate oneself from "the masses." In his essay "The Basic Motivation of the Creators and the Masses in The Fountainhead," Onkar Ghate (a member of the Ayn Rand Institute) articulates the kind of motivation Rand sees guiding the metaphorical architects of her utopia:

The root is that Roark's basic motivation in life is completely unconcerned with and unaffected by other people. His goal and his pursuit of it are purely independent and selfish...Roark's goal is to build. He wants to transform, for himself, the earth into his vision of a more uplifting, more human place. This desire would remain even on a desert island; only its implementation 
would change: he would not build gas stations or skyscrapers but, say, a hut or a cabin (245). Through Roark, her model of the ideal creative spirit, Rand aligns her utopian vision of the creative spirit with a state of internal, deeply resolute motivation. Traditionally utopias are considered imagined ideal communities, but Rand's creative ideal is a solitary state of mind unburdened by others' expectations.

Atlas Shrugged, Rand's next novel (released in 1957), continues to push on the utopian creative solitude of her heroes but introduces higher stakes as those internal utopian states of mind clash with a world leaning toward a dystopia for thinkers like Rand and her characters. The premise of Atlas Shrugged is that the world's tide shifts in the direction of nationalizing industry and redistributing wealth - a trend no doubt inspired by the spread of socialism and communism in the 1950s. As protagonist and railroad tycoon Dagny Taggart watches the mines becoming nationalized and innovative inventions destroyed, the world's moguls and innovators begin to vanish. Taggart continues resisting collectivization until she receives an invitation from the mysterious John Galt, a pioneer of individualism and reason, who has been persuading innovators to go on strike. Taggart joins Galt and the major composers, inventors, and industrialists in their utopian colony, watching as the collectivists languish and flail without guidance from the Randian-capitalist heroes. While The Fountainhead addresses the world and the masses in terms of a hypothetical, stiflingly mediocre form of groupthinking, the world of Atlas Shrugged places her philosophy and her heroes solidly in a context akin to her experience as a member of the Russian bourgeoisie, where the Bolsheviks' utopian, collectivist goals spelled dystopia and ruin for her family. Every detail through the eyes of the main character, Dagny Taggart, paints the dystopian world as one fading to gray with only echoes of the innovators who once shaped the world.

Once Dagny is accepted to join Galt's Gulch, the self-sustained, laissez-faire utopia to which all the innovators have disappeared, she and the reader are introduced to the book's essence, an enormous 30,000-word speech by John Glad, spoken almost directly to the reader, about what would formally become Objectivism.

In the extensive, exploratory biography, Ayn Rand and the Worlds She Made, Anne Heller recounts a story from the editing process for Atlas Shrugged: 
Pursuing what he thought was his editorial duty, [her editor], too, suggested a number of cuts, including cuts in John Galt's speech. When Rand refused, he appealed to Bennett Cerf [the firm's founding editor]. The high-spirited founding editor met with the author. "Nobody's going to read that," he told her. "You've said it all three or four times before...You've got to cut it." Answering with a comment that became publishing legend, she said, "Would you cut the Bible?" (282)

Like many others, Rand saw Atlas Shrugged as her magnum opus, but it was also much more than a work of literature to her. It was written as a living narrative of her philosophy, one in which the highs of her utopian visions could be realized and her brushes with dystopian Soviet collectivism could be weaponized in favor of her ideal brand of individualism and capitalism. Galt's speech, specifically, served a sort of Objectivist Manifesto, with decrees of radical individualism and rationality such as the following:

The most depraved sentence you can now utter is to ask: Whose reason? The answer is: Yours. No matter how vast your knowledge or how modest, it is your own mind that has to acquire it. It is only with your own knowledge that you can deal. It is only your own knowledge that you can claim to possess or ask others to consider. Your mind is your only judge of truth-and if others dissent from your verdict, reality is the court of final appeal. Nothing but a man's mind can perform that complex, delicate, crucial process of identification which is thinking. Nothing can direct the process but his own judgment. Nothing can direct his judgment but his moral integrity. (Rand, Atlas Shrugged 935)

As a sum of her experience and philosophy and as an ode to the industrious spirits of her father and grandfather, Atlas Shrugged is inseparable from its author. Rand and Atlas Shrugged mirror one another as Rand's striving to articulate a utopian state of being was, itself, living by that utopian ethic.

\section{MANIFESTING THIS UTOPIAN THOUGHT}

At the center of her narratives, Rand saw an ultimate purpose of worshipping the heroic ideal of man. That is, someone who embodies her ethics of internal motivation, unbridled creativity, and ruthless pursuit of his goals. Rand's goal, then, is to create a path to living like the ideal by first 
espousing it in her fiction. Many religious texts use the life and teachings of a central figure to model an ideal path and inspire a change in individuals' values-the Buddha and Jesus are good examples of such figures. Rand essentially uses that same, demonstrably powerful technique to present an antithesis to the messages of humility and altruism in these religious texts. Rand's ideal resonated enough to elevate her to a sort of guru at the head of a movement. Her often conservative, libertarian followers clamored for her treatises on the value of selfishness and evils of living for others. In placing utopian ideals on the individual in her fiction, she created a space for a "movement of individuals," itself a real-life utopian thought community, one that has grown over time and even been institutionalized with the Ayn Rand Institute and other, similar endeavors.

Even with the formal establishments to advance it, Objectivism first gained most of its converts and influence through Rand's novels. Despite its impact on the spread of her ideology, Rand had decidedly mixed and sometimes contradictory thoughts on the persuasive powers of literature. In her fiction, Rand often depicts literature as a tool to manipulate the weak-minded. She addresses this specifically in the critically-celebrated, yet unpopular author, Lois Cook from The Fountainhead. Cook's work, and literature in general, is hardly on Randian protagonist Howard Roark's radar: he is the self-driven man with little need for the outside guidance of literature. On the other hand, Peter Keating, one of Roark's dull, unambitious contemporaries, loves Cook's work precisely because he does not understand it: simply absorbing it makes him feel superior to others. To Rand, such literature written and read in bad faith; and the "it was profound, because he didn't understand it" attitude relies on a mutualistic relationship in which little-to-no meaning is made (qtd. in Brühwiler 6). The author earns praise by instilling in the reader a sense of inferiority and the reader feels unduly enlightened.

Rand levies a similar criticism against "propagandist" literature in support of socialist regimes portrayed in her fiction. According to political scientist Claudia Brühwiler, "The Communist regime, as Rand depicts it, obviously subscribes to the idea of literature's transformative power; otherwise, it would not censor individualistic novels and promote tales acting out Marxist clichés" (Walker 5). Rand derides "regime literature" for its use of hammy tragedy and unilateral thinking to create scenarios in which capitalists are unquestionably evil and, in turn, agitate the people against them. 
At the same time, however, Rand's literature champions the individual just as unambiguously as those communist tales of "a poor, honest worker" battered by capitalism. Her utopias are almost entirely black-and-white. The heroes are the earned, individualistic creators and the villains are unearned moochers and collectivists of the masses. Rand's interpretation of Aristotle's Poetics is telling of her own approach to persuasive literature: “Aristotle argues that 'fiction was more important than history' since fiction presents things 'as they might be and ought to be"' (Podritske and Schwartz 128). Rand uses wholly unambiguous worlds and characters to create the illusion that her utopia (whether it is a state of being or a world of laissez-faire capitalism) can be the only real option. As she divides, categorizes, and judges what ought to be (much like Aristotle), she makes truth claims that appeal only to one side of rationality, calling a different (probably equally rational) approach unfair and irrational.

This unambiguous thinking carries a definite allure: one can simply defer to the richly depicted truth in the novel. Brühwiler describes Rand's ideal role for readers, saying they "should not surrender to a plot and its heroines, but rather find a means to express themselves and resist whatever might lead them astray" (9). The critics and scholars who did express themselves and resist her sway were Rand's enemies because they subscribed to “non-Objectivist thought." Meanwhile her other enemies, the passive readers who came with the sweeping popularity of her fiction, would go on-in the spirit of deference to a powerful idea-to bring her utopian worlds into the real one. The paradox of Rand's utopian manifestations lies in the way the conquering power of her ideas creates devotees who, by becoming followers, immediately break with the spirit of Rand's utopian individualism. With her literature, Rand attempted to manifest a utopian ethic that would oppose a status quo she felt had harmed her. Despite her fervent defenses stating otherwise, she dealt in the methods of conversion she sought to diagnose-those with the black-and-white, see-the-world-through-my-fictional-one types of literature used in the religious and collectivist movements she so opposed.

The conquering power of Rand's fiction is best embodied by a scene from her own fiction. Rand's heroine Dominque Francon is perpetually downtrodden by seeing evil, anti-Objectivist people of the world win out over the heroes who earn their place. When she first sees Howard Roark-the rugged Randian hero of the story-she describes him as "the abstraction of strength made visible," 
before beginning her assertive days-long effort to seduce him (Rand, The Fountainhead, 247). Then, in one of the most notorious moments in The Fountainhead, Howard, after having learned of her desire, comes in uninvited and rapes her, despite her attempts to resist. Rand's camp often describes this scene as a forceful realization of her unconscious desire to be conquered by powerful individualism (Mayhew 206). Setting aside the horrible implications and rape apologetics involved in this interpretation, it offers an insight into the Randian view of their own Objectivist philosophy: that the beginning of a journey toward becoming a true individual starts with encountering the dominating force of an individual who lives for himself and is prepared to take what he wants.

Rand and her utopian heroes strive to act as that dominating force and, in large part, they have. Politicians and economists have gobbled up her works, finding affirmation and a guiding ethic for their conservative and libertarian views-and, in turn, cementing Rand's utopian narratives into crucial discussions about social security, welfare, and American capitalism as a whole. In a sense, Rand's unambiguous, convincing narratives of individualism and opportunity to stand out and earn one's place in the world helped systematize and engrain the very myths that drew her to the United States. In a 1991 Library of Congress survey, Americans named Atlas Shrugged the second most influential book in their lives, with the first being the Bible (Heller xii). We see the power of her utopian vision carry on today in an America in which billionaire moguls and the top one percent of society have been moralized to the point that one has been elected president. Her work's legacy carries on with continued high readership and a playing field of modern politics and economics run by people who look to Rand's ideal men as inspiration. As her legacy continues to stretch and become entrenched in American systems, looking to the utopian foundations of her thinking presents a distinct opportunity to unpack the motivations behind decades of Rand-inspired anti-socialist stigma, Reaganomics, Tea Party conservatism, and unwavering faith in capitalism. 


\section{WORKS CITED}

Brühwiler, Claudia. “'Prospector and Jeweler': Ayn Rand on the Relationship between Politics and Literature.” Journal of American Studies, vol. 49, no. 1, Feb. 2015, pp. 143-158. EBSCOhost, doi:10.1017/Soo21875814001820.

Ghate, Onkar. "The Basic Motivation of the Creators and the Masses in The Fountainhead." Essays on Ayn Rand's The Fountainhead, edited by Robert Mayhew, Lexington Books, 2007.

Heller, Anne. Ayn Rand and the World She Made. Random House, 2009.

Podritske, Marlene \& Schwartz, Peter, editors. Objectively Speaking: Ayn Rand Interviewed. Lexington Books, 2009.

Rand, Ayn. Atlas Shrugged. 1957. Penguin Group, 1992.

Rand, Ayn. The Fountainhead. 1943. Signet, 1996.

Walker, Jeff. The Ayn Rand Cult. Open Court Publishing, 1999.

\section{WORKS CONSULTED}

Bell-Villada, Gene H. “Who Was Ayn Rand?” Salmagundi, no. 141/142, 2004, pp. 227-242. JSTOR, www.jstor.org/stable/40549561.

Clardy, Alan. “Galt's Gulch: Ayn Rand's Utopian Delusion.” Utopian Studies, vol. 23, no. 1, 2012, pp. 238-262. JSTOR, www.jstor.org/stable/10.5325/utopianstudies.23.1.0238.

Hull, Gary, editor. The Ayn Rand Reader. Penguin Books, 1999.

Machan, Tibor. Ayn Rand. Peter Lang Publishing, 1999. 